\title{
Shoreline Change Analysis of Peat Soil Beach in Bengkalis Island Based on GIS and RS
}

\author{
Sigit Sutikno, Ari Sandhyavitri, Muhammad Haidar, and Koichi Yamamoto
}

\begin{abstract}
This paper presents an application of RS (remote sensing) and GIS (Geographic Information System) to analyze the spatial changes as well as quantify the shoreline change of Peat Soil Beach in Bengkalis Island, Riau Province, Indonesia. The area of Bengkalis Island is about $900 \mathrm{~km}^{2}$, of which $665 \mathrm{~km}^{2}$ is covered by peat more than $1 \mathrm{~m}$ thick. Landsat satellite images were used with a combination of histogram thresholding and band ratio method for shoreline change detection for last 26 years from 1988 to 2014. The statistical method called as LRR (Linear Regression Rate) and EPR (End Point Rate) in DSAS (Digital Shoreline Analysis System) was used to estimate the erosion and deposition rates. The shoreline of Bengkalis Island is dynamically changed over a time because abrasion rate is very high due to land use change in peat swamp forest. The maximum abrasion was $32.75 \mathrm{~m} / \mathrm{year}$ and $32.53 \mathrm{~m} / \mathrm{year}$ based on EPR and LRR methods respectively. Generally, either using EPR method or LRR method did not show a significant difference, although the LRR method tends to slightly underestimate.
\end{abstract}

Index Terms-Shoreline change, peat soil beach, GIS, RS.

\section{INTRODUCTION}

Riau province is located in northeast Sumatera Island, Indonesia that almost $51 \%$ of the area is covered with peat deposits; $93 \%$ of deposits are ombrogenous peat swamp forest. The lowland peat extends $450 \mathrm{~km}$ along the coast in Riau Province. Peat deposits cover most of the coastal low lands and the islands of Bengkalis, Padang, Tebingtinggi, Rangsang, Mendol, and Rupat. The area of this study focused in Bengkalis island, because the shoreline has significantly changed recently due to land use change and coastal hydrodynamic. The area of Bengkalis Island is about $900 \mathrm{~km}^{2}$, of which $665 \mathrm{~km}^{2}$ is covered by peat more than $1 \mathrm{~m}$ thick [1].

The shoreline change of peat soil beach in Bengkalis island was analyzed using historical remote sensing data based on Geographic Information System. Currently, the use of satellite imagery dataset is very important role in providing data for analysis and monitoring of coastal areas because the data are available in long time period. Landsat ETM+ (Enhanced Thematic Mapper) and TM (thematic mapper) with $15 \mathrm{~m}$ and $30 \mathrm{~m}$ spatial resolution are satellite dataset which can be used for analysis and monitoring of shoreline

\footnotetext{
Manuscript received February 15, 2016; revised April 25, 2016.

Sigit Sutikno and Ari Sandhyavitri are with Universitas Riau, Pekanbaru 28293, Indonesia (e-mail: ssutiknoyk@yahoo.com, ari.sandhyavitri@gmail.com).

Muhammad Haidar is with Geospatial Information Agency, Indonesia (e-mail: muhammad.haidar@big.go.id).

Koichi Yamamoto, Yamaguchi University, Japan (e-mail: k_yama@yamaguchi-u.ac.jp).
}

change [2]-[4]. Landsat satellite images, such as Landsat 5 TM, Landsat 7 ETM+ and Landsat 8 OLI (Operational Land Imager) were used with a combination of band ratio method for shoreline change detection for last 26 years from 1988 to 2014. Historical shoreline position of Bengkalis Island was extracted by applying image processing, such as geometric rectification, atmospheric correction, and on-screen shoreline digitizing.

With historical shoreline data input, the erosion and deposition rates can be estimated by overlaying using GIS tool. The rate of shoreline change can be calculated by DSAS (Digital Shoreline Analysis System), an extension for ArcGIS. DSAS is a digital shoreline analysis tool that can be used to compute rate-of-change statistics for a time series of historical shoreline data which is developed by United States Geological Survey (USGS) [5]. The DSAS has been successfully applied in many types of beach in the world, such as sandy beach [6], silt and clay beach [3], [7]. The tool can be used not only to compute the rate of shoreline change, but also to calibrate a numerical model for shoreline prediction [8], [9].

The statistical methods called as LRR (Linear Regression Rate) and EPR (End Point Rate) in DSAS were used in this study. The LRR method can be determined by fitting a least squares regression line to all shoreline points for a particular transect. The rate of shoreline change is the slope of the line. The EPR method is calculated by dividing the distance of shoreline movement by the time elapsed between the earliest and latest measurements. The both methods tend to give small differences for computed results in many cases [10], [11]. However, the LRR method is easier to employ and based on accepted statistical concepts with acceptable accuracy [12]-[14].

\section{METHODS}

\section{A. Study Area}

The study area is located in Bengkalis Island, Riau Province, Indonesia which lies $10 \mathrm{~km}$ off the coast of Sumatera along the west side of Malacca Strait as shown in Fig. 1. The island is almost flat and has maximum surface elevation of approximately $10-15 \mathrm{~m}$ above sea level. The maps of Bengkalis Island shows streams draining out of the peat deposits in a radial drainage pattern characteristic of domed peat deposits. The drainage pattern indicate that the peat deposit on the island is a group of peat domes each with a vortex surface topography. The peat deposits are five domes of peat having maximum thicknesses approximately 
of 6 to $10 \mathrm{~m} \mathrm{[1].}$

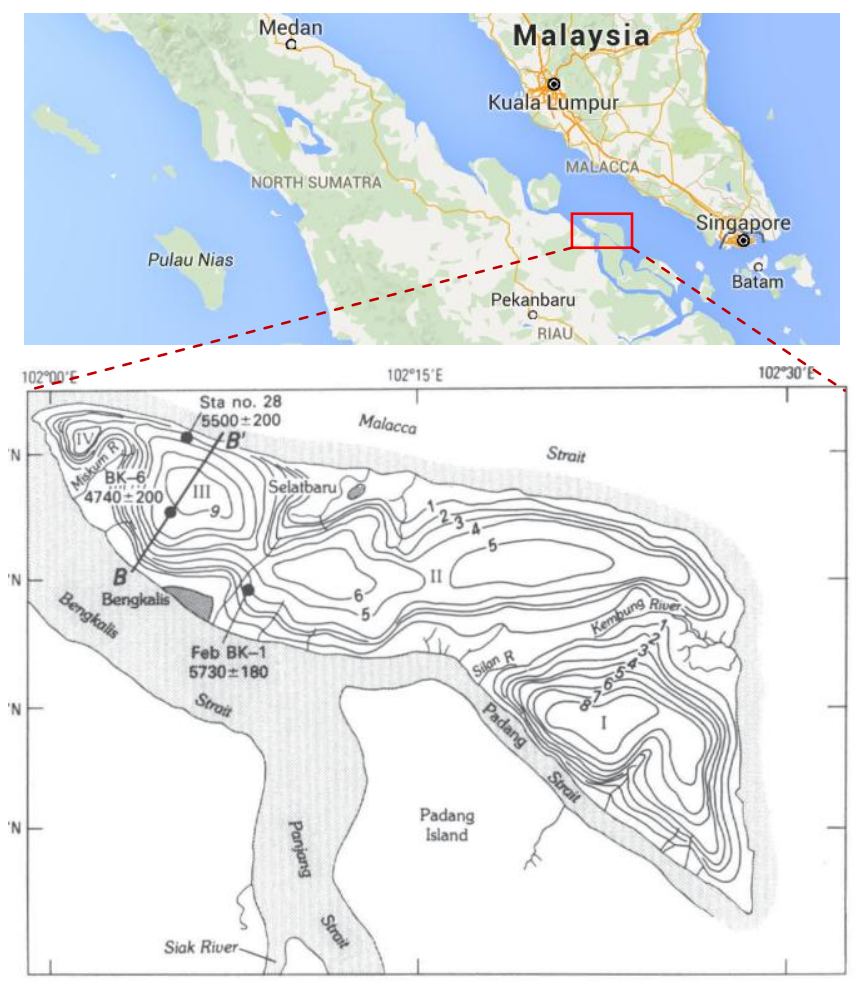

Fig. 1. The study area and the Isopach map of Bengkalis Island [1].

\section{B. Data}

Satellite data used in this study consisted of 5 years of data records, such as Landsat TM (Thematik Mapper) 1988, Landsat TM 2000, Landsat ETM+ (Enhanced Thematic Mapper) 2004, Landsat ETM+ 2010, and Landsat 8 OLI 2014. Landsat TM has a resolution of $30 \mathrm{~m}$, while the Landsat ETM+ and Landsat-8 OLI band 8 have a resolution of $15 \mathrm{~m}$. Path and Row position is on the Path 127 and Row 29 or UTM 40 N. Specifications of those satellite data are presented in Table I. Selection of the data were based on availability and quality of the satellite data.

TABLE I: LANDSAT DATA USED FoR THIS STUDY

\begin{tabular}{cccc}
\hline \hline Aquisition date & Satellite & Sensor & Resolution \\
\hline $07 / 31 / 1988$ & Landsat 5 & TM & $30 \mathrm{~m}$ \\
$03 / 10 / 2000$ & Landsat 5 & TM & $30 \mathrm{~m}$ \\
$07 / 19 / 2004$ & Landsat 7 & ETM+ & $15 \mathrm{~m}, 30 \mathrm{~m}$ \\
$01 / 09 / 2010$ & Landsat 7 & ETM+ & $15 \mathrm{~m}, 30 \mathrm{~m}$ \\
$01 / 20 / 2014$ & Landsat 8 & OLI & $15 \mathrm{~m}, 30 \mathrm{~m}$ \\
\hline \hline
\end{tabular}

\section{Methods}

Analysis and interpretation of Landsat data consists of cropping the image, image enhancement, geometric correction, digitization, and overlapping. Cropping the image was made to take the focus area of research to save storage in a computer memory. Image enhancement was the combination of bands needed to make clearer the boundary between land and water that will ease the process of digitization coastline. For Landsat TM and ETM+, the combination of histogram threshold and band ratio techniques is proposed by using band 2, 4, and 5 to separate water and land directly [2]. Other approach is to use single band thresholds such as band 5 or band 7 of Landsat TM and $\mathrm{ETM}+$ to extract water-land interface because they are useful in clear water conditions [15]. The Landsat image data were obtained in GeoTiff format which have been corrected so that the geometric correction was omitted. After classification, raster images would be converted to vector images. The final step is to export into shapefile format for processing in GIS tool.

Statistical analysis based on GIS was performed to determine the level of shoreline change or the rate of coastal erosion. This was done by using the software DSAS (Digital Shoreline Analysis System), an extension for ArcGIS. Shoreline analysis using DSAS consists of three main stages, such as : 1) to set up baseline parallel to the shoreline as the reference line, 2) to choose parameter for transects perpendicular to the baseline that divides coastline in sections, and 3) to calculate the rate of change each section. Linear Regression Rates (LRR) method and End Point Rate (EPR) method, two statistical method that were chosen to present the computational results. The LRR can be determined by fitting a least squares regression line to all shoreline points for a particular transect as shown in Fig. 2 [5]. The regression line is placed so that the sum of the squared residuals (determined by squaring the offset distance of each data point from the regression line and adding the squared residuals together) is minimized. The rate of shoreline change is the slope of the line. The advantages of linear regression include : a) all the data are used, regardless of change in trend or accuracy; b) the method is purely computational; c) it is based on accepted statistical concepts; and d) it is easy to employ.

The end point rate is calculated by dividing the distance of shoreline movement by the time elapsed between the oldest and the most recent shoreline as shown in Fig. 3. The major advantages of the EPR are the ease of computation and minimal requirement of only two shoreline dates. The major disadvantage is that in cases where more data are available, the additional information is ignored.

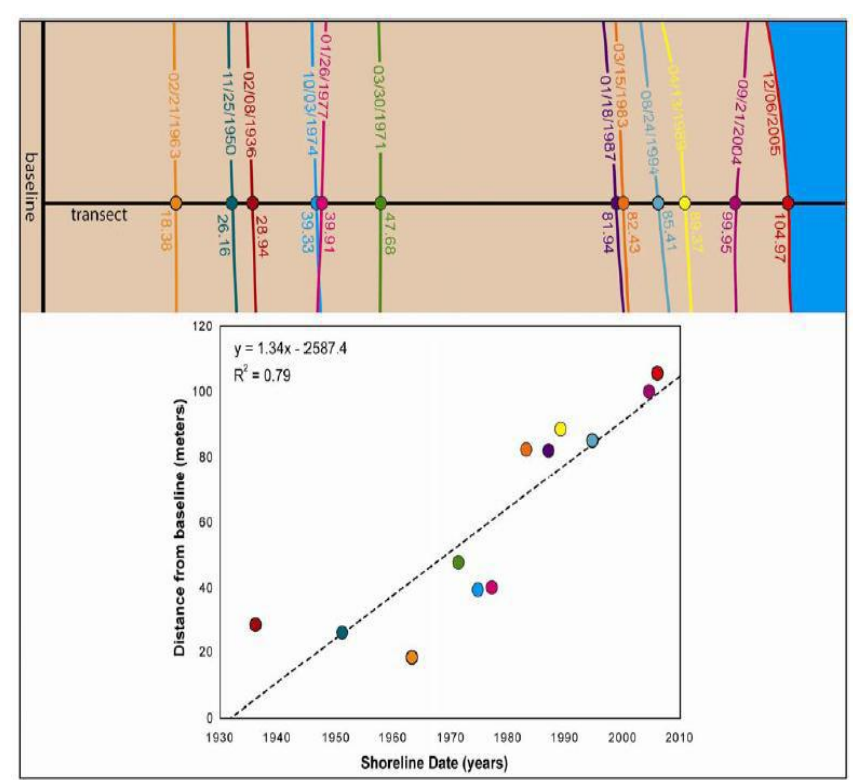

Fig. 2. The method of LRR calculation [5]. 


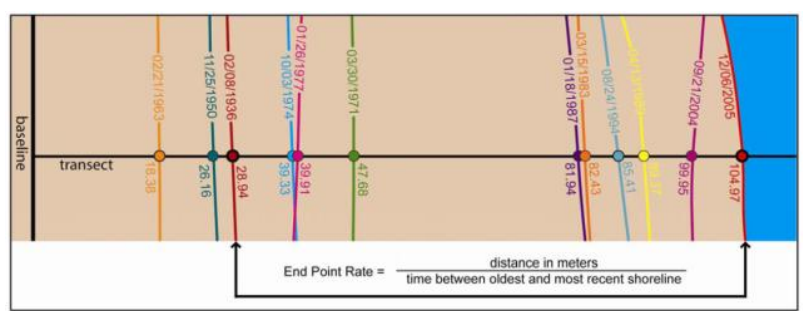

Fig. 3. The method of EPR calculation [5].

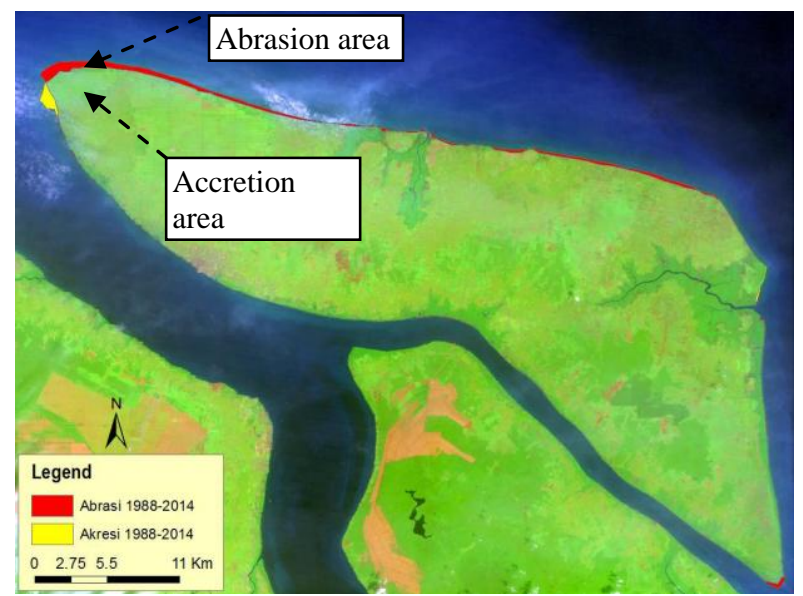

Fig. 4. Abrasion and accretion area of Bengkalis Island during $1988 \sim 2014$

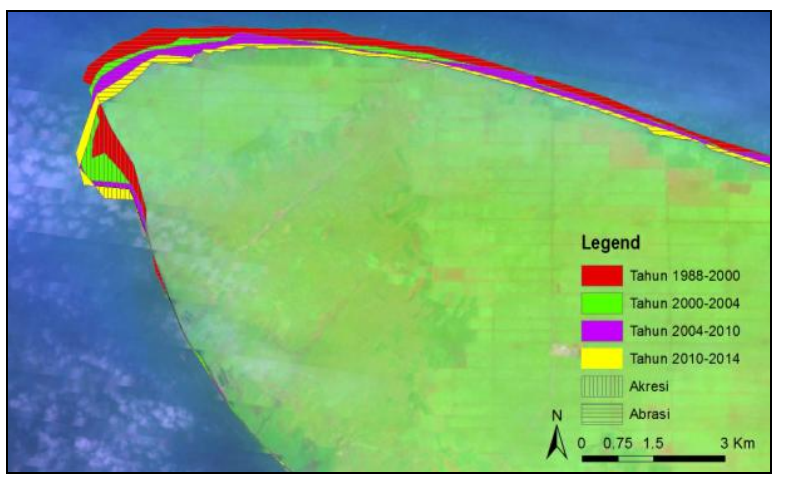

Fig. 5. Historical abrasion and accretion area of Bengkalis Island during $1998 \sim 2014$.

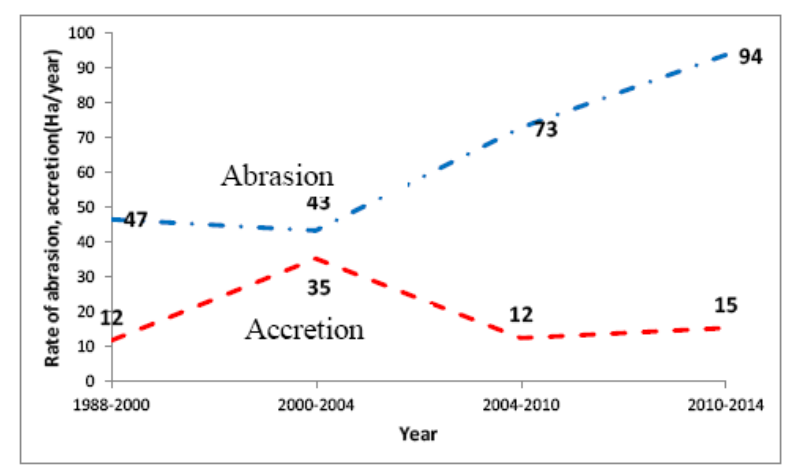

Fig. 6. Rate of abrasion and accretion of the Bengkalis Island during 1988-2014.

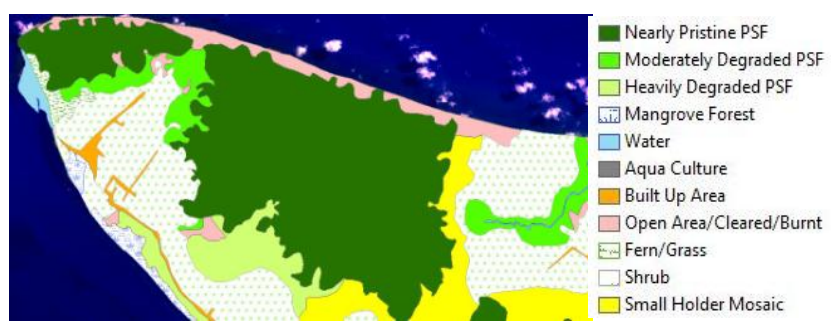

Fig. 7. Land cover in west part of the Bengkalis Island in 1988.

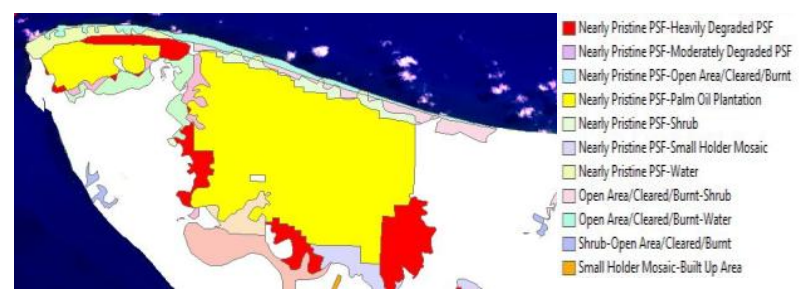

Fig. 8. Dominant Land cover change in west part of the Bengkalis Island in 2004-2013.

\section{RESULTS AND DISCUSSIONS}

\section{A. Identification of Shoreline Change}

The image processing, such as cropping, enhancement, and correction were applied for 5 years of Landsat data records. By image processing and digitizing, the historical shorelines data of Bengkalis Island for the last 26 years can be extracted from Landsat. From the extracted shoreline data, the historical of shoreline change can be analyzed by overlaying process. Identification of coastal abrasion and coastal accretion during 26 years, from 1998 to 2014 can be carried out by overlaying the oldest and the newest shorelines, and the result is shown in Fig. 4. The figure shows that most of the north side of Bengkalis Island occur abrasion with various level the rate of shoreline change. The most damage level of abrasion occurred in the western end of the island. However, the accretion processes occurred in the south side of the west Bengkalis Island. For the next detail discussion, this study focused on the west part of Bengkalis Island.

Fig. 5 shows the more detail historical shoreline change of Bengkalis Island in the west part in 1988, 2000, 2004, 2010, and 2014. It shows that the abrasion occurred along the north side of Bengkalis Island, while the accretion occurred in the south side. This phenomenon shows that beach material were transported from north side to the south by drift current and diffraction process.

\section{B. Rate of Abrasion and Accretion Change}

The rate of abrasion and accretion in Bengkalis Island during some specific time periods is shown in Fig. 6. It shows that the abrasion rate during 1988-2000 and during 2000-2004 were $47 \mathrm{ha} /$ year and $43 \mathrm{ha} /$ year respectively. The abrasion rate increased significantly after 2004. During 2004-2010 and 2010-2014, the abrasion rate were $73 \mathrm{ha} /$ year and $94 \mathrm{ha} /$ year respectively. To investigate the causes of high abrasion in the west part of Bengkalis Island during these time periods, an analysis of land use change was done. The analysis was performed by using historical Landsat data. The results showed that there were a significant land use change after 2004 as shown in Fig. 7 and Fig. 8. The figures show that the land use change was dominantly from peat swamp forest to palm oil plantation. Those changed areas were about 11,653 ha. Those significant land use changes from 2004 to 2013 correspond with the rate of abrasion in that time period. It means that the high abrasion in the west part of Bengkalis Island is mainly caused by the land use change from peat swamp forest to palm oil plantation.

However, the average rate of accretion in Bengkalis Island was about 12-35 ha/year. From this analysis can be estimated 
that, during the period of last 26 years, Bengkalis coast has suffered abrasion area about 1,504.93 ha and accretion area about 419.39 ha. This mean that, during the last 26 year, Bengkalis Island has lost the land area about 1,085.54 ha, or an average of $42.57 \mathrm{ha} /$ year.

\section{Shoreline Change Mechanism}

After the landuse change significantly from peat swamp forest to palm oil plantation in the west part of Bengkalis Island, the water balance in this area have not been well distributed in time and space. Many canals have been made for plantation purpose that have been made this area easy dried. This made the water table lower and peat material in the surface became dry especially in the dry season. When the rainy season comes, the precipitation will increase the mass of the peat soil through increasing the water content. This will reduce the stability of peat slopes that will cause peat failure. The evidences show that the failures usually occur in the rainy season as shown in Fig. 9. The figures show that there was no peat failure in June $21^{\text {st }} 2014$ which was in dry season. After rainy season, on January 15, 2015, many peat failures were occured along the north side of Bengkalis coast. Fig. 10 also shows an evidence that peat slope failure have occured in west part of Bengkalis Island. There is a straight road which was initially smooth on August 2013, but seven months after it became a terraced road because of sliding in that area. This evidence indicates that bog burs peat failures have been occurred in west part of Bengkalis Island.
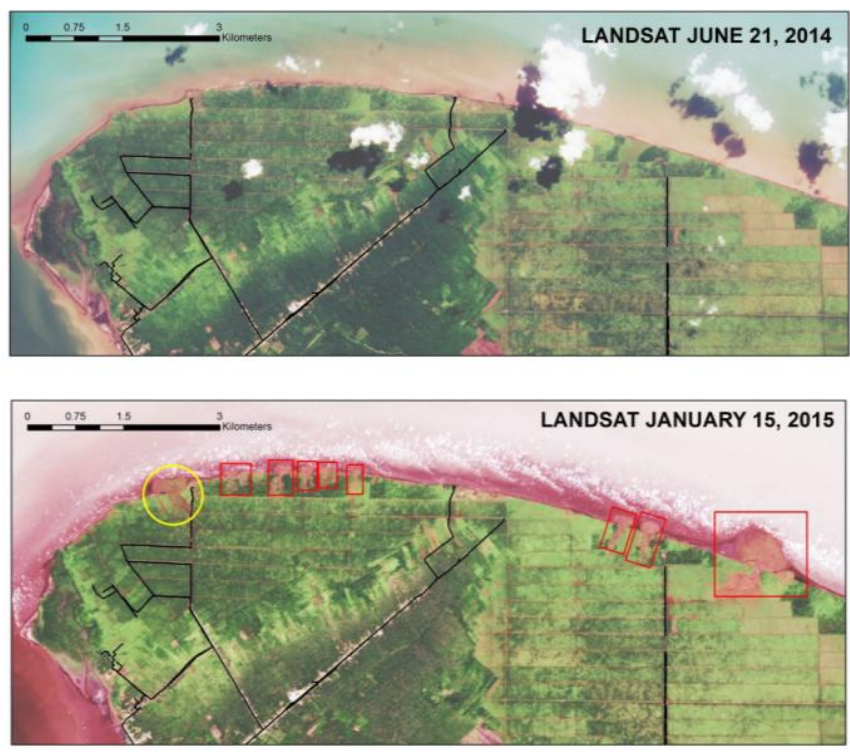

Fig. 9. Peat failure in coastal area of Bengkalis Island.

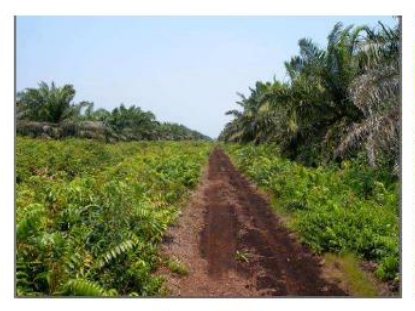

August 2013

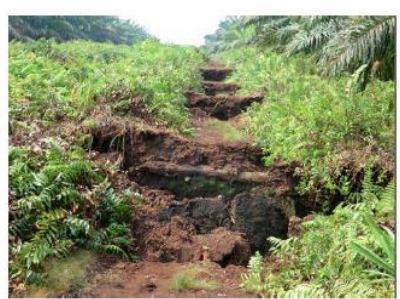

March 2014

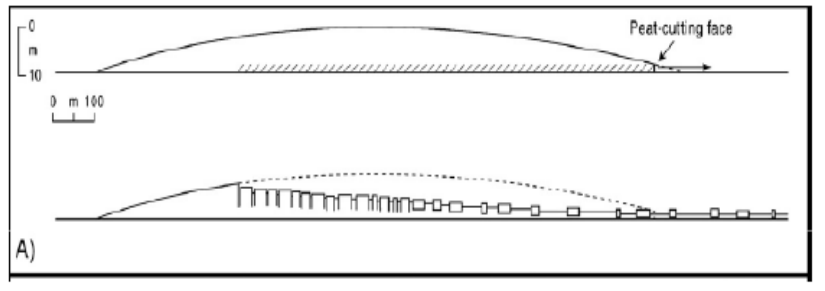

Fig. 10. Bog burs peat failure evidence in Bengkalis Island.

Peat failure in the coastline area will generate a movement amout of peat material to the coastal area as shown in Fig. 9. These peat materials were very easy to be transported by current drift because these peat were relatively very light material. The wind rose data around Bengkalis coast show that the dominant wind direction is from north-east [12]. The wind have generated dominant wave also from north-east direction. As a result, this caused longshore sediment transport from east to the west direction. The dominant wave also have been deflected in the west end of Bengkalis Island which have caused a wave diffraction process. The wave diffraction process had an important role on sedimentation process in the south side of the west Bengkalis Island.

\section{Rate of Shoreline Change}

In order to quantify the rate of abrasion and accretion more detail in a specific location, then further analysis using the DSAS (Digital Shoreline Analysis System) software has been conducted. The analysis was performed on shoreline change data record for five years, ie 1988, 2000, 2004, 2010, and 2014. As a reference to the shoreline change for each of these years, it were made baselines that were parallel to the shoreline. Multiple shoreline positions along with fictitious baseline are the basic requirement for analyzing the shoreline. Long-term rates of change were calculated for entire study areas at each transect for 26 years i.e. 1988 to 2014 using EPR and LRR method considering 7 datasets. Fig. 11 shows a result of the shoreline change analysis for west part of Bengkalis Island. There are 118 transects established in this zone with 500 meter interval. The figure shows the rate of shoreline change in each transect number as a results from DSAS tool. It can be seen from the figure that the positive and negative rates of change show the beach accretion and beach abrasion correspondingly.

Fig. 11 shows the rate of shoreline change of Bengkalis Island using EPR Method whereas Fig. 12 shows the comparison of Rate of shoreline change of Bengkalis Island using both EPR and LRR Method. The analysis showed that the maximum rate of abrasion occurred in the western part of the Bengkalis Coast, ie around transect number- 8 as shown in Fig. 11. The rate of abrasion at this site_are about 32.75 $\mathrm{m} /$ year and $32.53 \mathrm{~m} /$ year based on EPR and LRR methods respectively. The rate of abrasion tends to decrease in the eastward of Bengkalis Island. Unlike the abrasion process that occurs along the northern coast of the Bengkalis Island, beach accretion process only occurs in the west coast of Bengkalis Island with approximately $3 \mathrm{~km}$ long. The maximum rate of accretion are about $39.21 \mathrm{~m} /$ year and 44.52 $\mathrm{m} /$ year based on EPR and LRR method respectively. That was occurred around transect number 5 . 
Generaly, the results of the rate of shoreline change method tends to slightly underestimate. estimation either using EPR method or LRR method did not show a significant difference, as shown in Fig. 12. The LRR

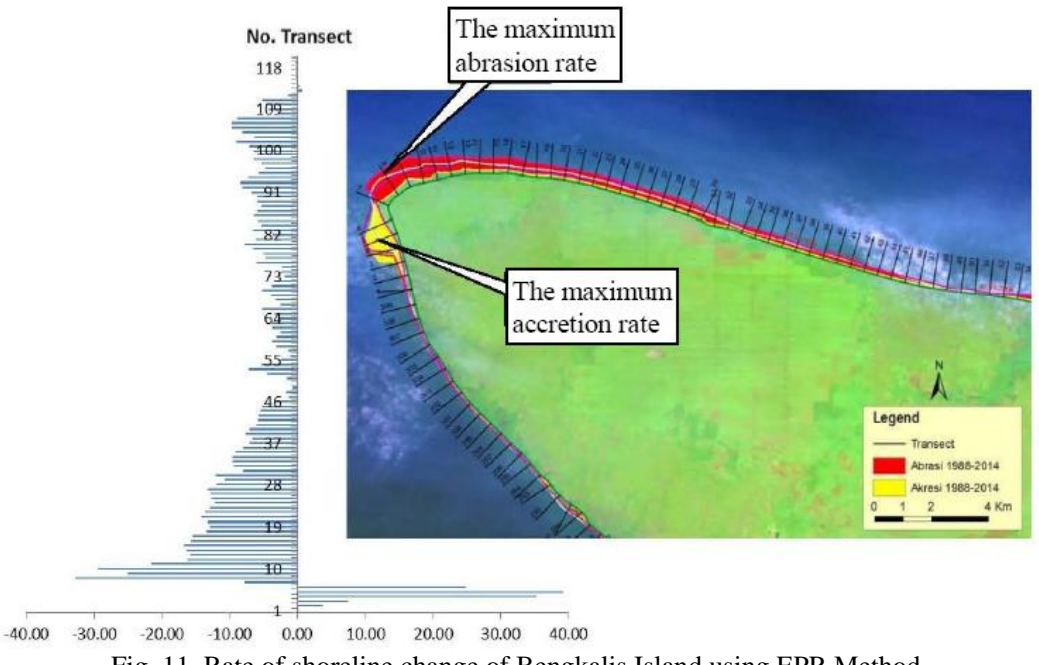

Fig. 11. Rate of shoreline change of Bengkalis Island using EPR Method

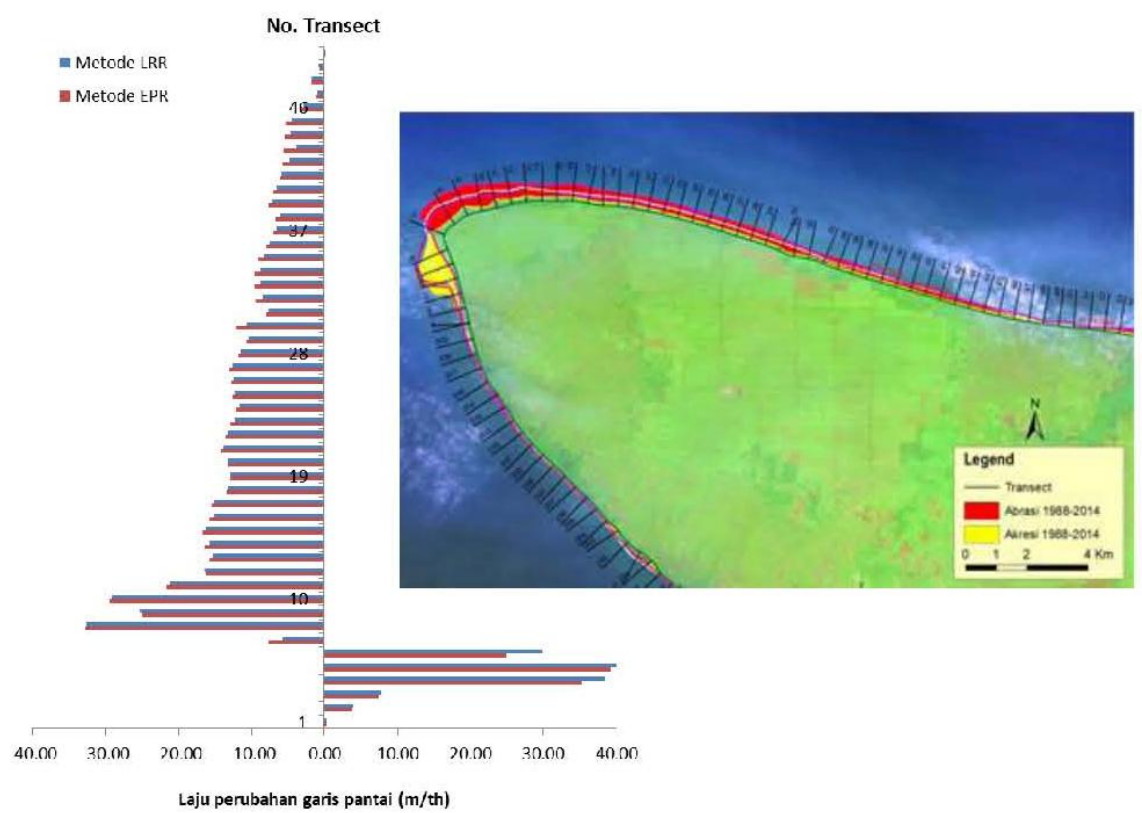

Fig. 12. Comparison of Rate of shoreline change of Bengkalis Island using EPR and LRR Method

\section{CONCLUSION}

The integration between remote sensing and GIS technology is very useful because it can be used to overview the long-term shoreline changes in the concerned area quickly. The paper showed that the rate of shoreline change could be calculated by statistical method which was built in the extension of GIS tool. Quantitatively, the shoreline of Bengkalis Island is dynamically changed over a couple of year because abrasion rate is very high due to land use change in peat swamp forest. The maximum abrasion was 32.75 $\mathrm{m} /$ year and $32.53 \mathrm{~m} /$ year based on EPR and LRR methods respectively. Generaly, either using EPR method or LRR method did not show a significant difference, although the LRR method tends to slightly underestimate. It should be noted that peat soil beach is very vulnerable against the wave and the distribution of water in time and space.

\section{ACKNOWLEDGMENT}

The authors would like to thank the Directorate General of Higher Education (DIKTI) - Ministry of Research, Technology and Higher Education for its 2014-2015 Post Graduate research grants program (PPS).

\section{REFERENCES}

[1] Supardi, A. D. Subekty, and S. G. Neuzil, "General geology and peat resources of the Siak Kanan and Bengkalis Island peat deposits, Sumatra, Indonesia," Modern and Ancient Coal-Forming Environments, 1993, pp. 45-62.

[2] A. A. Alesheikh, A. Ghorbanali, and N. Nouri, "Coastline change detection using remote sensing," Int. J. Environ. Sci. Technol., vol. 4, no. 1, pp. 61-66, 2007.

[3] S. Sutikno, F. Fatnanta, and A. R. I. Kusnadi, "Integrated remote sensing and GIS for calculating shoreline change in rokan estuary," in Proc. the 1st International Conference on Science and Engineering, 2015 . 
[4] H. M. El-Asmar and M. E. Hereher, "Change detection of the coastal zone east of the Nile Delta using remote sensing," Environ. Earth Sci., vol. 62, no. 4, pp. 769-777, 2011.

[5] E. R. Thieler, E. A. Himmelstoss, J. Zichichi, and A. Ergul, "Digital shoreline analysis system (DSAS) version 4.0 - An arcgis extension for calculating shoreline change," 2009.

[6] M. Albuquerque, J. Espinoza, and P. Teixeira, "Erosion or coastal variability: An evaluation of the DSAS and the change polygon methods for the determination of erosive processes on sandy beaches," J. Coast. Res., no. 65, pp. 1710-1714, 2013.

[7] S. R. Ahmad and V. C. Lakhan, "GIS-based analysis and modeling of coastline advance and retreat along the coast of guyana," Mar. Geod., vol. 35, no. 1, pp. 1-15, 2012.

[8] S. Sutikno, K. Murakami, D. P. Handoyo, and M. Fauzi, "Calibration of numerical model for shoreline change prediction using satellite imagery data," Makara J. Technol., vol. 19, no. 3, pp. 113-119, 2015.

[9] S. Sutikno, D. P. Handoyo, M. Fauzi, and K. Murakami, "Model numerik untuk simulasi alternatif perlindungan pantai berbasis sistem informasi geografis," in Proc. ACES (Annual Civil Engineering Seminar), vol. 1. pp. 227-234, 11-Jan-2016.

[10] D. V. To and P. T. P. Thao, "A Shoreline analysis using DSAS in narn dinh: Coastal area," Int. J. Geoinformatics, vol. 4, no. 1, pp. 37-42, 2008.

[11] K. Abu-alhin and I. Niemeyer, "Calculation of erosion and accretion rates along the gaza coastal zone using remote sensing and," in Proc. 4th EARSeL Work. Remote Sens. Coast. Zo., June, 2009.

[12] S. Sutikno, "Rate of shoreline change analysis of bengkalis coast using satellite imagery data," in Proc. the 31st Annual Conference of Indonesian Association of Hydraulic Engineer, 2014, pp. 616-625.

[13] W. P. Beach, A. S. Genz, C. H. Fletcher, R. A. Dunn, L. N. Frazer, and J. J. Rooney, "The predictive accuracy of shoreline change rate methods and alongshore beach variation on Maui, Hawaii," J. Coast. Res., vol. 23, no. 1, pp. 87-105, 2007.

[14] R. S. Kankara, S. C. Selvan, B. Rajan, and S. Arockiaraj, "An adaptive approach to monitor the Shoreline changes in ICZM framework: A case study of Chennai coast," Indian J. Mar. Sci., vol. 43, no. July, 2014.

[15] S. Bagli and P. Soile, "Morphological automatic extraction of pan-european coastline from landsat ETM+ images," in Proc. 5th Int. Symposium on GIS and Computer Cartography for Coastal Zone Management, Integrating Information in Coastal Zone Management, Genova, 2003.

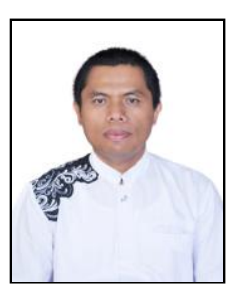

Eng. Sigit Sutikno was born in OKU, South Sumatera, Indonesia on June $16^{\text {th }} 1974$. Dr. Sutikno finished his doctoral degree in coastal engineering from University of Miyazaki, Japan on March 2012.

$\mathrm{He}$ is a senior lecturer and a researcher in civil engineering department, Universitas Riau, Indonesia. His last publications are: Calibration of Numerical Model for Shoreline Change Prediction Using Satellite
Imagery Data, 2015; Integrated Remote Sensing and GIS for Calculating Shoreline Change in Rokan Estuary, 2015; Application of Spatial and Network Analysis to Evaluate Shelter Plan for Tsunami Evacuation, 2015. His current research project is mitigation strategy to coastline change along coast of riau province using mathematical modeling based on GIS and remote sensing.

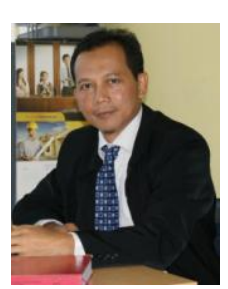

Ari Sandhyavitri was graduated from Civil and Structural Engineering University of Manchester Institute of Science and Technology (UMIST), in 2002. He worked as a senior member of the Universal Association of Civil, Structural and Environmental, a member of the Construction Service Development Board (LPJK) as Highway Engineer. He is a lecture at the Civil Engineering Department, Engineering Faculty, University of Riau, Pekanbaru, Indonesia. His current research interest are decision support systems, water supply infrastructure, mitigating of natural disaster, and wetland environment.

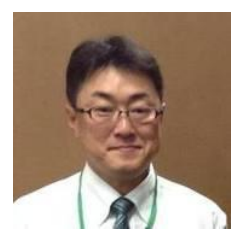

Koichi Yamamoto was born in Sapporo, Japan on September $6^{\text {th }} 1973$. Yamamoto. He finished his doctoral degree in School of Engineering from Hokkaido University, Japan in 2002.

$\mathrm{He}$ is an associate professor, Graduate School of Science and Engineering, Yamaguchi University, Japan. His last publications are: Development of New Erosion Measurement Device for Cohesive Sediment with Digital Camera and its Application, 2014; Peat Coast Erosion of the Bengkalis Island and its Effect on the Groundwater Discharge, 2014. His current research project is Peat-coast erosion by the degradation of the mangroves and formation processes of the newly established substitute tidal flat ecosystem.

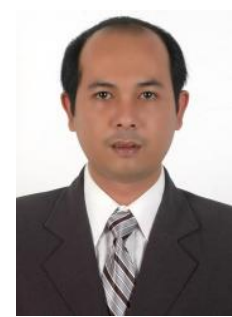

Muhammad Haidar was born in Yogyakarta, Indonesia on July $22^{\text {nd }}, 1982$. Haidar finished his master degree in Graduate School of Science and Engineering, Yamaguchi University, Japan on March 2015.

He is a staf in Geospatial Information Agency of Indonesia. His last publications are: Peat Failures (Mass Movements) in Bengkalis Island's Tropical Peatlands, Carbon Emission From Degraded Peatland in Bengkalis Island Indonesia, Organic Carbon and Nutrients Content of Peat Materials in Bengkalis Island Indonesia. 